\title{
Improvement of bacterial blight resistance of the popular variety, Nellore Mahsuri, NLR34449 through marker-assisted breeding
}

\section{Aleena D}

Indian Institute of Rice Research

Padma V

ANGRAU

Rekha G

Indian Institute of Rice Research

Dilip T

Indian Institute of Rice Research

Punniakotti E

Indian Institute of Rice Research

Kousik MBVN

Indian Institute of Rice Research

Laxmi prasanna B

Indian Institute of Rice Research

Swapnil RK

Indian Institute of Rice Research

Pragya Sinha

Indian Institute of Rice Research

Harika G

Indian Institute of Rice Research

Kale RR

Indian Institute of Rice Research

\section{Das MA}

Indian Institute of Rice Research

Hajira SK

Indian Institute of Rice Research

Anila M

Indian Institute of Rice Research

Pranathi K

Indian Institute of Rice Research

Mastanbee shaik

Indian Institute of Rice Research

Laha GS

Indian Institute of Rice Research

Prasad MS

Indian Institute of Rice Research

Balachandran SM

Indian Institute of Rice Research

Subbarao LV

Indian Institute of Rice Research

Ratna Babu D

Acharya N G Ranga University

Lal Ahamed M 
Acharya NG Ranga Agricultural University

Ramana JV

Acharya NG Ranga Agricultural University

Vijaya Gopal A

Acharya N G Ranga University

Raman Sundaram ( $\nabla$ rms_28@rediffmail.com )

Indian Institute of Rice Research https://orcid.org/0000-0002-9857-8251

\section{Original article}

Keywords: NLR 34449, Rice, BB, Blast, Marker Assisted Introgression

Posted Date: August 28th, 2020

DOI: https://doi.org/10.21203/rs.3.rs-66828/v1

License: @ (1) This work is licensed under a Creative Commons Attribution 4.0 International License. Read Full License 


\section{Abstract}

To combat the dreaded diseases in rice like bacterial blight and blast, host plant resistance has been advocated as a sustainable method. Through the present study, we have successfully incorporated three major bacterial blight (BB) resistance genes viz., Xa21, xa13 and $x a 5$ into NLR3449, a high yielding, blast resistant, fine-grain type popular rice variety through marker-assisted backcross breeding. Foreground selection was carried out using PCR based, gene-specific markers viz., pTA248 (Xa21), xa13prom (xa13) and xa5FM (xa5) at each generation of backcrossing, while 127 polymorphic SSR markers spanning on 12 chromosomes were used for background selection and backcrossing was limited to two rounds. $\mathrm{At}_{\mathrm{BC}} \mathrm{F}_{1}$ generation, a single plant (NLR-87-10) with $89.9 \%$ recovery and possessing all the three bacterial blight resistance genes was forwarded to $B_{2} F_{2}$ generation. A solitary $B C_{2} F_{2}$ plant viz., NLR-87-10-106 possessing all the three resistance genes and $>90 \%$ genome recovery was identified and advanced through selfing till $\mathrm{BC}_{2} \mathrm{~F}_{4}$ generation by adopting pedigree method. Three best lines at $\mathrm{BC}_{2} \mathrm{~F}_{4}$ lines, possessing high level of resistance against bacterial blight and blast and equivalent or superior to NLR 34449 in terms of yield, grain quality and agro-morphological traits have been identified and advanced for multi-location trials.

\section{Introduction}

Rice is an important food crop that serves as a major carbohydrate source for nearly half of the world's population (Nguyen and Ferrero 2006; Sundaram et al. 2008 and Pradhan et al. 2015). It is grown throughout the year in a variety of agro-ecosystems in India, which include irrigated, rain-fed, deep-water and hills (Sundaram et al. 2009). We need to produce at least $40 \%$ more rice by 2030 to feed a growing population and there are many challenges in meeting the food security requirements for the future (Khush 2005). This target has to be met amidst the scarcity of natural resources and adverse effects from a rapidly changing climate and with less use of chemicals and unde constant battle against new emerging pathogens and pests (Pradhan et al. 2015). Rice is affected by many diseases and among them, bacterial blight (BB) caused by Xanthomonas oryzae pv. oryzae (Xoo) (Ishiyama, 1922) is known to cause yield losses ranging from $74 \%-81 \%$ (Srinivasan and Gnanamanickam 2005), when the disease occurs in severe form. BB is particularly severe in the irrigated and rain-fed lowland ecosystems (Sundaram et al. 2008). The disease occurs in the host plant at seedling, vegetative and reproductive stages, but infection at the tillering stage causes severe blighting of leaves resulting in yield loss (Shivalingaiah and Umesha 2011). Chemical control for BB is cost intensive and not effective as successful bactericidal chemicals are not available (Devadath 1989). Thus, the exploitation of disease resistant cultivars is the most effective and eco-friendly approach for reducing yield losses due to BB (Sundaram et al. 2008). At least, 45 BB resistant genes (Neelam et al. 2019; Sundaram et al. 2014; Suk-man Kim et al. 2018) have been identified so far from the primary gene pool of rice and pyramiding two or more resistance genes has been advocated to enhance the durability of resistance (Sundaram et al. 2008).

The rice variety, NLR 34449, popularly known as Nellore Mahsuri, was released from Rice Research Station, Acharya N.G. Ranga Agricultural University, Nellore, Andhra Pradesh, India. It is popular among the rice farmers of South India, as it is high yielding, possesses highly desirable medium slender (MS) grain type, has excellent blast resistance, is of short duration (120 days), possesses non-lodging plant type and is highly amenable for machine harvesting. It is highly preferred rice by the farmers of Andhra Pradesh and other South Indian states (http://www.kvknellore-angrau.org/index.php). Despite its high yield and blast resistance, the variety is highly susceptible to bacterial blight disease, which limits its production and adoption significantly. Keeping these points in view, through the present study, we have transferred three major bacterial blight resistance conferring genes, viz., Xa21, xa13 and xa5from elite, fine grain, BB resistant variety Improved Samba Mahsuri (ISM) into the genetic background of NLR 34449 through markerassisted backcross breeding (MABB).

\section{Material And Methods:}

\section{Plant material:}

NLR 34449 (popularly known as Nellore Mahsuri), a high yielding, medium slender, blast resistant and short duration variety (120-125 days) developed from the cross IR 72/BPT 5204 in the year 2009 was used as the recurrent parent. Improved Samba Mahsuri (ISM), a high yielding, medium-slender grain type, bacterial blight (BB) resistant variety developed by ICAR-Indian Institute of Rice Research (ICAR-IIRR), Hyderabad, India and CSIR-Centre for Cellular and Molecular Biology (CSIR-CCMB), Hyderabad, India, possessing three major bacterial blight (BB) resistance genes, viz., Xa21, xa13 and xa5 (Sundaram et al. 2008) was used as the donor parent for bacterial blight resistance. 


\section{Marker-assisted backcross breeding strategy:}

NLR 34449 was crossed with Improved Samba Mahsuri during dry season 2016-17. $F_{1} s$ developed from the above mentioned cross were confirmed for their heterozygosity using target resistance gene specific markers viz., pTA248 specific for Xa21 (Ronald et al. 1992), xa13prom, specific for $x a 13$ (Hajira et al. 2016) and xa5FM specific for $x a 5$ (Hajira et al. 2016). True $F_{1} s$ thus identified were then backcrossed with the recurrent parent, NLR 34449 to generate $B C_{1} F_{1}$ s. They were subjected for foreground selection using genespecific markers and positive plants (i.e. plants which are heterozygous for all the three target BB resistance genes) were then analyzed for the recurrent parent genome recovery through background selection using a set of 127 SSR parental polymorphic markers evenly distributed across the 12 rice chromosomes (listed in Supplementary Table 1B) to identify those plants with maximum recurrent parent genome recovery (RPG). A single $B_{1} F_{1}$ plant positive for all three target genes and with maximum recurrent parent genome recovery was selected and backcrossed with NLR 34449 to generate $\mathrm{BC}_{2} \mathrm{~F}_{1}$ s. Marker-assisted foreground and background selection was repeated among the $\mathrm{BC}_{2} \mathrm{~F}_{1}$ plants and a single $\mathrm{BC}_{2} \mathrm{~F}_{1}$ plant possessing the target resistance genes and also with maximum recurrent genome recovery were selfed to develop $\mathrm{BC}_{2} \mathrm{~F}_{2}$ s. Finally, a single $\mathrm{BC}_{2} \mathrm{~F}_{2}$ plant possessing $X a 21$, xa13 and $x a 5 \mathrm{in}$ homozygous condition along with maximum RPG and closely resembling NLR 34449 (based on morphological features) was identified and advanced through pedigree method of breeding till $\mathrm{BC}_{2} \mathrm{~F}_{4}$ (Figure 1). The extent of donor parent segment introgression among the selected backcross derived plants at $\mathrm{BC}_{2} \mathrm{~F}_{4}$ generation was assessed utilizing the software tool, Graphical Genotype $V 2.0$ (Van Berloo, 1999) and the $\mathrm{BC}_{2} \mathrm{~F}_{4: 5}$ lines were also further evaluated for bacterial blight resistance and key agro-morphological traits.

\section{Phenotypic screening for BB and blast resistance:}

\section{Bacterial blight screening:}

Thirty-day old seedlings of the improved breeding lines of NLR 34449 at $\mathrm{BC}_{2} \mathrm{~F}_{4}$ generation were transplanted in the main field of experimental farm of ICAR-IIRR located at Rajendranagar, Hyderabad, India to assess their resistance against bacterial blight during wet season 2019. IX0-20, a local virulent isolate (collected from Hyderabad, Telangana State, India) of Xanthomonas oryzae pv. oryzae was used for screening of bacterial blight resistance of the breeding lines. Inoculation was done at maximum tillering stage following leaf clip method of Kauffman et al. 1973 by clipping the leaf tip (about 1 to $2 \mathrm{~cm}$ ) of the uppermost leaf with scissors dipped into the inoculum. Symptoms were measured at 15 days after inoculation based on the IRRI SES (IRRI, 2013) for their resistance/susceptibility.

\section{Screening for blast resistance:}

During dry season 2019-20, gene pyramided lines possessing $X a 21$, xa13 and xa5at $\mathrm{BC}_{2} \mathrm{~F}_{5}$ generation were analysed for their resistance against blast in uniform blast nursery along with the susceptible (HR12) and resistant (C101A51 and Tetep) checks using a local isolate, SPI-40 of the blast pathogen, Magnaporthae oryzae as per the protocol described in Mohan et al. (2011). After 15days of inoculation, the lines were scored for their resistance/ susceptibility to the disease based on IRRI-SES scale, 1996 (IRRI, 1996).

\section{Screening of the improved lines for agro-morphological characters:}

During dry season 2020, thirty-day old seedlings of the recurrent parent NLR 34449 and donor parent ISM along with five best backcross derived lines at $\mathrm{BC}_{2} \mathrm{~F}_{5}$ generation, possessing bacterial blight resistant genes in the genetic background of NLR 34449 were transplanted in the main field of experimental farm of ICAR-IIRR located at Rajendranagar, Hyderabad, India at a spacing of $15 \mathrm{X}$ $20 \mathrm{~cm}$ in $2 \mathrm{~m}^{2}$ plots in three replications and the field was applied with the recommended dose of NPK fertilizers (@220:70:80kg/ha). Phenotypic data was collected for the selected plants for key agro-morphological traits, viz., plant height (cm), days to $50 \%$ flowering (DFF), panicle length $(\mathrm{cm})$, number of productive tillers per plant, panicle exertion, grain yield per 33 plants (i.e. per $\mathrm{m}^{2}$; in g), number of grains per panicle, grain type, L/B ratio, 1000-grain weight $(\mathrm{g})$ among 33 plants for each replication $(\mathrm{n}=3)$ as explained in Abhilash et al. (2016). The data was statistically analysed as per the procedure described in Freeman et al. (1978). Least Significance Difference (LSD) values at 5 to 7 percent level of significance and Coefficient of variation (CV) were calculated using standard errors of mean (S. Em. \pm ) using Microsoft Excel package. The software package, $R$ studio (R Core, 2016) was used for analysis of variance (ANOVA) to determine significant variation among the improved breeding lines of NLR 34449.

\section{Results:}


Ninety-five $F_{1}$ plants, which were derived from the cross NLR 34449 X ISM were confirmed for their hybridity with respect to the three target BB resistance genes i.e., Xa21, xa13 and xa5 with the help of gene-specific markers viz., pTA248, xa13prom and xa5FM, respectively during wet season2017. A total of $80 \mathrm{~F}_{1}$ plants were found to be heterozygous for all the three target $\mathrm{BB}$ resistant genes. These plants (i.e. Xa21xa21 xa13Xa13 xa5Xa5) were used as pollen donors to develop $\mathrm{BC}_{1} \mathrm{~F}_{1}$ s. Among $175 \mathrm{BC}_{1} \mathrm{~F}_{1 \mathrm{~s}}, 21$ plants were found to be heterozygous for all the three target BB resistant genes (i.e. Xa21, xa13 and xa5). These 21 plants were analyzed to assess the recovery of the recurrent parent genome using a set of 127 parental polymorphic primers (Supplementary table 1A, 1B) and the analysis revealed that a single $\mathrm{BC}_{1} \mathrm{~F}_{1}$ plant (NLR-87) had the highest recurrent parent genome (RPG) recovery of $78.5 \%$. The plant, NLR-87 was then used as a pollen donor to produce $\mathrm{BC}_{2} \mathrm{~F}_{1}$ s. A total of $105 \mathrm{BC}_{2} \mathrm{~F}_{1}$ plants were raised and evaluated through foreground selection with gene-specific markers and thirteen were found to be positive for all the three target $\mathrm{BB}$ resistant genes and they were subjected for background genome recovery analysis with parental polymorphic SSR markers and a single plant (NLR-87-10) with maximum recurrent parent genome re recovery (89.9\%) was identified. This plant was selfed to produce $\mathrm{BC}_{2} \mathrm{~F}_{2}$ plants. $\mathrm{A}$ total of $425 \mathrm{BC}_{2} \mathrm{~F}_{2}$ plants, which were generated by selfing the selected $\mathrm{BC}_{2} \mathrm{~F}_{1}$ plant (NLR-87-10), were grown in the field. All of them were subjected to phenotypic screening with a local isolate of $\mathrm{XOO}$, IXO-20 at maximum tillering stage to screen for their resistance against BB. A total of 359 plants were found to be resistant.

When the phenotypically resistant plants were subjected for foreground selection with the help gene-specific markers, a total of five plants were identified to be homozygous for all the three target resistant genes (Figure 2). A solitary plant (NLR-87-10-106) which was homozygous resistant to all the three target resistant genes and possessed with maximum recovery of NLR34449 genome (94.6\%) was identified and was advanced further through pedigree method of breeding to $\mathrm{BC}_{2} \mathrm{~F}_{4}$ generation. The details of number of plants screened and selected in each generation of backcrossing were given in Table 1. A set of five promising $B_{2} \mathrm{~F}_{4}$ lines, viz., (NLR-87-10106-40-50, NLR-87-10-106-41-51, NLR-87-10-106-42-52, NLR-87-10-106-43-53, NLR-87-10-106-44-54) identified to be identical to recurrent parent NLR 34449 with respect to morphological traits and these lines were subjected for analysis of their resistance against bacterial blight, blast, yield and agro-morphological traits.

Table 1: Details of number of plants confirmed for foreground and background selection among the backcross population

\begin{tabular}{|llllll|}
\hline $\begin{array}{l}\text { S. } \\
\text { No }\end{array}$ & Generation & $\begin{array}{l}\text { Total no. of } \\
\text { plants analysed }\end{array}$ & $\begin{array}{l}\text { Total no. positive plants to all } \\
\text { three target genes } \\
(\text { Xa21, xa13, xa5) }\end{array}$ & $\begin{array}{l}\text { \% of Recurrent Parent } \\
\text { Genome (RPG) recovery }\end{array}$ & $\begin{array}{l}\text { Selected plant with } \\
\text { maximum RPG\% }\end{array}$ \\
\hline 1 & $\mathrm{~F}_{1}$ & 95 & 11 & - & NLR-87 \\
\hline 2 & $\mathrm{BC}_{1} \mathrm{~F}_{1}$ & 175 & 20 & $78.5 \%$ & NLR-87-10 \\
\hline 3 & $\mathrm{BC}_{2} \mathrm{~F}_{1}$ & 105 & 13 & $89.9 \%$ & NLR-87-10-106 \\
\hline 4 & $\mathrm{BC}_{2} \mathrm{~F}_{2}$ & 318 & 5 & $94.6 \%$ & (i) NLR-87-10-106-40- \\
\hline 5 & $\mathrm{BC}_{2} \mathrm{~F}_{4}$ & & $96 \%$ & 50 \\
& & & & (ii) NLR-87-10-106-41- \\
& & & 51 & (iii) NLR-87-10-106-42- \\
& & & 52 \\
& & & (iv) NLR-87-10-106-43- \\
& & & 53 \\
& & & (v) NLR-87-10-106-44- \\
\hline
\end{tabular}

\#The true $F_{1}$ s obtained from the cross between Nellore Mahsuri (NLR34449) x Improved Samba Mahsuri were backcrossed with Nellore Mahsuri. The best $\mathrm{BC}_{1} \mathrm{~F}_{1}$ plant was identified through foreground and background selection was backcrossed with Nellore Mahsuri to generate $\mathrm{BC}_{2} \mathrm{~F}_{1} \mathrm{~s}$. The best $\mathrm{BC}_{2} \mathrm{~F}_{1}$ plant (identified through foreground and background selection was selfed to produce 
$\mathrm{BC}_{2} \mathrm{~F}_{2}$ s. Selected homozygous $\mathrm{BC}_{2} \mathrm{~F}_{2}$ plant with maximum RPG\% was selfed and advanced through pedigree method of breeding to $\mathrm{BC}_{2} \mathrm{~F}_{4}$ generation.

The five selected $\mathrm{BC}_{2} \mathrm{~F}_{4}$ lines were further analysed to assess the extent of linkage drag around the target bacterial blight resistant genes i.e., Xa21, xa13 and xa5. This analysis revealed that for Xa21 gene located on Chr. 11L, a segment of $0.3 \mathrm{Mb}$ was introgressed at both proximal and distal ends from the donor parent genome in the best $\mathrm{BC}_{2} \mathrm{~F}_{4}$ plant (NLR-87-10-106-40-50); thus, in total, a segment of $0.6 \mathrm{Mb}$ was introgressed from the donor parent with respect to the genomic region in the vicinity of $X a 21$ (Figure 3A). With respect to xa13 gene located on $\mathrm{Chr}$. $8 \mathrm{~L}$, a segment of $0.5 \mathrm{Mb}$ was introgressed at proximal end while another segment of $0.8 \mathrm{Mb}$ was introgressed at distal end from the donor parent genome in the best $\mathrm{BC}_{2} \mathrm{~F}_{4}$ plant (NLR-87-10-106-40-50); thus, in total, a segment of $1.3 \mathrm{Mb}$ was introgressed from the donor parent with respect to the genomic region in the vicinity of $x a 13$ (Figure 3B). With respect to xa5 gene located on $\mathrm{Chr}$. $5 \mathrm{~S}$, a segment of $0.2 \mathrm{Mb}$ was introgressed at proximal end, while $0.3 \mathrm{Mb}$ introgressed at distal end from the donor parent genome in the best $\mathrm{BC}_{2} \mathrm{~F}_{4}$ plant (NLR-87-10-106-40-50); thus, in total, a segment of $0.5 \mathrm{Mb}$ was introgressed from the donor parent with respect to the genomic region in the vicinity of $x a 5$ (Figure $3 \mathrm{C}$ ). All the five selected introgressed $\mathrm{BC}_{2} \mathrm{~F}_{4}$ lines were subjected to screening for bacterial blight and blast resistance and also evaluated for their agro-morphological traits.

\section{Assessment of BB and Blast resistance in the improved lines of NLR 34449:}

The donor parent Improved Samba Mahsuri (ISM), RPBio- Patho- 1 and RPBio- Patho- 2 were observed to be highly resistant to the disease with a lesion length ranging from 0.0 to $1.7 \pm 0.3$ (Score 1). The recurrent parent, NLR 34449 was observed to be highly susceptible to the disease with a lesion length of $8.7 \pm 0.0$ (Score 9) when screened with IXO-20. All the five selected $\mathrm{BC}_{2} \mathrm{~F}_{4}$ were observed to be resistant to BB disease, showing a lesion length of 0-1 cm, which was similar to the donor parent (i.e. ISM) (Fig 4A, Table 2). With respect to blast disease, the susceptible check, HR12 and the parent, donor ISM were highly susceptible to blast, with a score of 9, while the resistant check, Tetep and the recurrent parent, NLR 34449 were found to be resistant to the disease with a score of 1 and 3 , respectively. The selected $\mathrm{BC}_{2} \mathrm{~F}_{5}$ lines were observed to show resistant reaction against blast disease with a disease score of 2-4 (Fig 4B, Table 2)

Table 2: Reaction of selected improved lines of NLR 34449 after inoculation with bacterial blight and blast pathogen

\begin{tabular}{|lllll|}
\hline Parents and checks & \multicolumn{3}{l}{ Reaction against BB } & \multicolumn{2}{l|}{ Reaction against Blast } \\
\cline { 2 - 5 } & IXO-20 & \multicolumn{3}{l|}{ SP140 } \\
\cline { 2 - 5 } & Score & R/S & Score & R/S \\
\hline ISM & $0.0 \pm 0.0$ & $\mathrm{R}$ & 9 & $\mathrm{~S}$ \\
\hline NLR 34449 & $8.7 \pm 0.0$ & $\mathrm{~S}$ & 3 & $\mathrm{R}$ \\
\hline RPBio- Patho 1 & $1.3 \pm 0.3$ & $\mathrm{R}$ & 2 & $\mathrm{R}$ \\
\hline RPBio- Patho 2 & $1.7 \pm 0.3$ & $\mathrm{R}$ & 1 & $\mathrm{R}$ \\
\hline TN1 & $8.7 \pm 0.3$ & $\mathrm{~S}$ & - & - \\
\hline HR12 & - & - & 9 & $\mathrm{~S}$ \\
\hline NLR-86-10-106-40-50 & 1 & $\mathrm{R}$ & 2 & $\mathrm{R}$ \\
\hline NLR-86-10-106-41-51 & 1 & $\mathrm{R}$ & 3 & $\mathrm{R}$ \\
\hline NLR-86-10-106-42-52 & 1 & $\mathrm{R}$ & 3 & $\mathrm{R}$ \\
\hline NLR-86-10-106-43-53 & 1 & $\mathrm{R}$ & 4 & $\mathrm{R}$ \\
\hline NLR-86-10-106-44-54 & 1 & $\mathrm{R}$ & 3 & $\mathrm{R}$ \\
\hline
\end{tabular}

${ }^{\#}$ R- Resistant; S-Susceptible

Evaluation of Agro-morphological traits and data analysis in the improved lines of NLR 34449 
Among the improved lines, $\mathrm{BC}_{2} \mathrm{~F}_{4}$ plant, NLR-87-10-106-44-54 displayed better attributes with respect to most of the agromorphological traits when compared to the recurrent parent, Nellore mahsuri. All the introgressed lines were slightly taller than the recurrent parent, Nellore Mahsuri and shorter than donor parent, Improved Samba Mahsuri, except a single line NLR-87-10-106-42-52 $(75.5 \pm 0.9 \mathrm{~cm})$ which was observed to be slightly shorter than recurrent parent (Table 3). The introgressed lines were found to perform equivalent or better than both the recurrent as well as donor parents in terms of panicle length, number of grains per panicle, thousand grain weight and grain yield per plant with good panicle exertion (Figure 5, Table 3). Two improved lines, NLR-87-10-106-40-50 and NLR-87-10-106-42-52 recorded grain yield per plant $(24.1 \pm 0.6 \mathrm{~g})$ equivalent to the recurrent parent. The analysis of variance for ten agro-morphological traits among the selected $\mathrm{BC}_{2} \mathrm{~F}_{4}$ lines and the recurrent parent, Nellore Mahsuri revealed that the mean sum of squares due to treatments $(<0.01)$ were highly significant for all the traits under study, indicating significant variability among the lines as compared to Nellore Mahsuri (Table 3). For genetic parameters such as genotypic coefficient of variance (GCV) and phenotypic coefficient of variance (PCV), lower values (0-10\%) was recorded in days to fifty percent flowering (DFF), plant height (PH), panicle length $(\mathrm{PL})$, number of grains per panicle (NGP), thousand grain weight and L/B ratio and moderate values (10-20\%) for productive tillers, grain yield per plant. Values for heritability in broad sense was noticed moderate ( $>50 \%)$ in days to $50 \%$ flowering (DFF), plant height, panicle length, number of grains per panicle, L/B ratio and to be high for remaining traits $(>60 \%)$. For Genetic advance in $\%$ of mean (GAM) lower values were (0-10\%) observed in days to $50 \%$ flowering (DFF), plant height, panicle length, L/B ratio and moderate $(10-20 \%)$ in number of grains per panicle, thousand seed weight and higher $(>20 \%)$ with respect to the remaining traits (Table 3$)$.

Table 3: Evaluation of agro-morphological characters in the improved lines along with parents under field conditions 


\begin{tabular}{|c|c|c|c|c|c|c|c|c|c|c|c|}
\hline $\begin{array}{l}\text { S. } \\
\text { No. }\end{array}$ & $\begin{array}{l}\text { Plant } \\
\text { identity }\end{array}$ & $\begin{array}{l}\text { Days to } \\
50 \% \\
\text { flowering } \\
\text { (DFF) }\end{array}$ & $\begin{array}{l}\text { Mean } \\
\text { plant } \\
\text { height } \\
\text { (cm) }\end{array}$ & $\begin{array}{l}\text { No. of } \\
\text { productive } \\
\text { panicles/plant }\end{array}$ & $\begin{array}{l}\text { Panicle } \\
\text { length } \\
\text { (cm) }\end{array}$ & $\begin{array}{l}\text { Number } \\
\text { of } \\
\text { grains } \\
\text { per } \\
\text { panicle }\end{array}$ & $\begin{array}{l}\text { Grain } \\
\text { Yield } \\
\text { per } \\
\text { plant } \\
\text { (g) }\end{array}$ & $\begin{array}{l}1000 \\
\text { seed } \\
\text { weight } \\
\text { (g) }\end{array}$ & $\begin{array}{l}\text { L/B } \\
\text { ratio }\end{array}$ & $\begin{array}{l}\text { Grain } \\
\text { type }\end{array}$ & $\begin{array}{l}\text { Panicle } \\
\text { exertion }\end{array}$ \\
\hline 1 & $\begin{array}{l}\text { NLR } \\
34449\end{array}$ & $\begin{array}{l}95.0 \pm \\
0.3\end{array}$ & $\begin{array}{l}77.0 \pm \\
0.3\end{array}$ & $13.7 \pm 0.3$ & $\begin{array}{l}22.0 \pm \\
0.6\end{array}$ & $\begin{array}{l}242.0 \pm \\
1.5\end{array}$ & $\begin{array}{l}24.0 \pm \\
0.3\end{array}$ & $\begin{array}{l}14.1 \pm \\
0.6\end{array}$ & $\begin{array}{l}2.70 \pm \\
0.00\end{array}$ & MS & $\mathrm{FE}$ \\
\hline 2 & $\begin{array}{l}\text { RPBio- } \\
226\end{array}$ & $\begin{array}{l}101.0 \\
\pm 1.2\end{array}$ & $\begin{array}{l}84.0 \pm \\
0.6\end{array}$ & $12.3 \pm 0.9$ & $\begin{array}{l}19.2 \pm \\
0.6\end{array}$ & $\begin{array}{l}225.0 \pm \\
1.2\end{array}$ & $\begin{array}{l}17.1 \pm \\
1.7\end{array}$ & $\begin{array}{l}12.5 \pm \\
0.7\end{array}$ & $\begin{array}{l}2.70 \pm \\
0.00\end{array}$ & MS & PE \\
\hline 3 & $\begin{array}{l}\text { NLR-87- } \\
10-106- \\
40-50\end{array}$ & $\begin{array}{l}97.3 \pm \\
0.3\end{array}$ & $\begin{array}{l}77.7 \pm \\
0.4\end{array}$ & $17.0 \pm 0.0$ & $\begin{array}{l}22.5 \pm \\
0.6\end{array}$ & $\begin{array}{l}268.0 \\
\pm 1.2\end{array}$ & $\begin{array}{l}24.1 \pm \\
0.2\end{array}$ & $\begin{array}{l}14.3 \pm \\
0.2\end{array}$ & $\begin{array}{l}2.70 \pm \\
0.00\end{array}$ & MS & $\mathrm{FE}$ \\
\hline 4 & $\begin{array}{l}\text { NLR-87- } \\
10-106- \\
41-51\end{array}$ & $\begin{array}{l}101.0 \pm \\
0.6\end{array}$ & $\begin{array}{l}78.2 \pm \\
0.9\end{array}$ & $16.0 \pm 0.6$ & $\begin{array}{l}22.1 \pm \\
0.3\end{array}$ & $\begin{array}{l}273.0 \pm \\
0.9\end{array}$ & $\begin{array}{l}24.7 \pm \\
0.4\end{array}$ & $\begin{array}{l}14.2 \pm \\
0.2\end{array}$ & $\begin{array}{l}2.70 \pm \\
0.00\end{array}$ & MS & $\mathrm{FE}$ \\
\hline 5 & $\begin{array}{l}\text { NLR-87- } \\
10-106- \\
42-52\end{array}$ & $\begin{array}{l}99.0 \pm \\
0.6\end{array}$ & $\begin{array}{l}75.5 \pm \\
0.9\end{array}$ & $16.3 \pm 0.3$ & $\begin{array}{l}22.5 \pm \\
0.3\end{array}$ & $\begin{array}{l}272.0 \pm \\
0.9\end{array}$ & $\begin{array}{l}24.1 \pm \\
0.6\end{array}$ & $\begin{array}{l}14.5 \pm \\
0.1\end{array}$ & $\begin{array}{l}2.70 \pm \\
0.00\end{array}$ & MS & FE \\
\hline 6 & $\begin{array}{l}\text { NLR-87- } \\
10-106- \\
43-53\end{array}$ & $\begin{array}{l}99.0 \pm \\
0.3\end{array}$ & $\begin{array}{l}77.7 \pm \\
0.6\end{array}$ & $16.7 \pm 0.9$ & $\begin{array}{l}23.0 \pm \\
0.4\end{array}$ & $\begin{array}{l}263.0 \pm \\
1.5\end{array}$ & $\begin{array}{l}26.8 \pm \\
0.5\end{array}$ & $\begin{array}{l}15.0 \pm \\
0.1\end{array}$ & $\begin{array}{l}2.70 \pm \\
0.00\end{array}$ & MS & $\mathrm{FE}$ \\
\hline \multirow[t]{9}{*}{7} & $\begin{array}{l}\text { NLR-87- } \\
10-106- \\
44-54\end{array}$ & $\begin{array}{l}94.0 \pm \\
0.9\end{array}$ & $\begin{array}{l}79.0 \pm \\
0.6\end{array}$ & $17.7 \pm 0.3$ & $\begin{array}{l}23.8 \pm \\
0.3\end{array}$ & $\begin{array}{l}280.0 \pm \\
0.9\end{array}$ & $\begin{array}{l}28.8 \pm \\
0.3\end{array}$ & $\begin{array}{l}16.1 \pm \\
0.1\end{array}$ & $\begin{array}{l}2.70 \pm \\
0.00\end{array}$ & MS & $\mathrm{FE}$ \\
\hline & Mean & 97 & 78.04 & 15.67 & 22.15 & 260 & 24.23 & 14.37 & 2.68 & & \\
\hline & CV (\%) & 2.7 & 3.7 & 6.5 & 5.45 & 5.61 & 5.50 & 5.08 & 2.61 & & \\
\hline & $F_{\text {cal }}$ value & 3.14 ** & $3.5^{\star \star}$ & $10.63^{\star *}$ & $4.36^{\star \star}$ & $5.56^{\star \star}$ & $21.94^{\star \star}$ & $6.42^{\star \star}$ & 3.02 ** & & \\
\hline & GCV & 2.27 & 3.36 & 11.75 & 5.77 & 6.91 & 14.53 & 6.83 & 2.14 & & \\
\hline & PCV & 3.51 & 4.99 & 13.46 & 7.94 & 8.9 & 15.53 & 8.51 & 3.38 & & \\
\hline & $h^{2} b(\%)$ & 41.69 & 45.37 & 76.25 & 52.84 & 60 & 87.47 & 64.36 & 40.25 & & \\
\hline & LSD@5\% & 4.67 & 5.12 & 1.83 & 2.15 & 26.01 & 2.37 & 1.3 & 0.12 & & \\
\hline & GAM@5\% & 3.02 & 4.66 & 21.14 & 8.64 & 11.06 & 27.99 & 11.28 & 2.8 & & \\
\hline
\end{tabular}

${ }^{\#} \mathrm{CV}$ - Coefficient of Variation, PCV - Phenotypic Coefficient of Variance, GCV - Genotypic Coefficient of Variance, h2 b - broad sense of Heritability, $f(\mathrm{Cal})$ - F test calculated; LSD - Least Significant Difference; GAM - Genetic advance in \% of mean; MS - Medium Slender; FE - Full Exserted, and PE - Partially Exserted.

\section{Discussion:}

Rice yield and productivity is drastically reduced due to two major diseases, viz., bacterial blight (BB) and blast (Ou 1985; Srinivas prasad et al. 2009). Development of improved versions of crop varieties through introgression of resistance genes with the help of molecular markers has been well demonstrated with respect to blast disease (Ashkani et al. 2014; Hari et al. 2013; Manu et al. 2012; Madhavi et al. 2013, 2016; Rekha et al. 2018) and BB management (Joseph et al. 2004; Sundaram et al, 2008, 2009, 2011). Till date, at least 45 BB resistance genes (Kim, 2018; Kumari Neelam et al. 2019; Sundaram et al. 2014) have been identified. Among them, the major, dominant, broad spectrum bacterial blight resistance gene, Xa21 (originally derived from O. longistaminata) located on Chr. 11, a major recessive gene located on chromosome 8, xa13 another major recessive gene located on chromosome 5, xa5 are known to confer broad spectrum and durable resistance against the disease (Lalitha et al. 2013; Pradhan et al. 2015; Ramalingam et al. 2017; Rekha et al. 2018; Sundaram et al. 2008, 2009).

NLR 34449, popularly known among farmers as Nellore Mahsuri, was released from Rice Research Station, Acharya N.G. Ranga Agricultural University (ANGRAU), Nellore, Andhra Pradesh, India. This variety is popular among the farmers, as it is high yielding, 
semi-dwarf in plant stature, blast resistant, early maturing (120 days) and is non-lodging type (suitable for machine harvesting). It is highly preferred by rice farmers in the states of Andhra Pradesh, Telangana and other South Indian states (http://www.kvknelloreangrau.org/index.php). Further, it possesses medium-slender grain type, which is highly desirable among the rice consumers in South India and varieties with medium-slender grain type like Samba Mahsuri, Sona Mahsuri etc. are getting increasingly popular across India. As NLR 34449 is highly susceptible to bacterial blight disease, we attempted to improve NLR 34449 for durable bacterial blight resistance by using marker assisted introgression of three bacterial blight resistance genes, Xa21, xa13 and xa5.

In breeding programmes, molecular markers that are tightly linked to target genes/QTLs are very useful to overcome the limitations of conventional phenotype based breeding and improve the selection efficiency of target genes or traits in backcross breeding programmes (Jena and Mackill, 2008). This is especially through 'foreground selection' where markers are used alone or in combination with phenotypic screening in selection for the target trait(s) (Hospital and Charcosset, 1997). In the present study, the codominant markers, pTA248 (Ronald et al. 1992), xa13prom and xa5FM (Hajira et al. 2016) were used to screen for the presence of three bacterial blight resistance genes, viz., Xa21, xa13 and xa5 respectively and all the three markers are reported to be functional markers or very closely linked for the respective genes, with no chance or very little chance for recombination (Hajira et al. 2016). These markers were also used by Ramalingam et al. (2017) and Rekha et al. (2018). The strategy of combining phenotyping with genotyping for BB resistance in the later generation of backcrossing/selfing has been reported earlier by Hari et al. $(2011 ; 2013)$, wherein a stringent phenotypic screening initially followed by selective genotyping of resistant plants has been reported to save time and resources. This is because; marker-assisted selection was done with only plants which exhibited phenotypic resistance against the targeted stress. Moreover, the segregation pattern with respect to bacterial blight resistance in phenotypic screening in $\mathrm{F}_{2}$ generation was observed to be 55:9 as the target genes include two recessive genes (viz., xa13 and xa5). These plants were advanced for evaluation of their disease resistance, agro-morphological traits at $\mathrm{BC}_{2} \mathrm{~F}_{4}$ generations

Marker-assisted backcross breeding (MABB) strategy is very helpful in reducing the number of backcrosses needed for complete recovery of the recurrent parent genome (RPG). Even though there are reports which suggest that a minimum of three to four backcrosses are required for near complete recovery of recurrent parent genome (Bai et al. 2006; Hasan et al. 2015a; Sundaram et al. 2008; Sundaram et al. 2009), our recent experience and that of other studies suggest that by adopting a stringent MABB strategy, the number of backcrosses can be limited to just two and still we can maximize the recurrent parent genome recovery (Abhilash et al. 2017; Basavaraj et al. 2010; Singh et al. 2001, Miah et al. 2015; Rekha et al. 2018, Swathi et al. 2019).

Marker-assisted background selection in the early backcross generations has been advocated for quick recovery of the recurrent parent genome (Chen et al. 2001 and Joseph et al. 2004). Polymorphic microsatellite markers are usually utilized for background selection in order to assess the recovery of the recurrent parent genome and also to shorten the number of backcross generations (Hospital and Charcosset, 1997) to estimate the amount of recurrent parent genome contribution. Similar study has been done by (Abhilash kumar et al. 2015; Anila et al. 2014; Balachiranjeevi et al. 2015; Bhaskar et al.2015; Mahadevaswamy et al. 2018; Rekha et al. 2018).

The donor parent and recurrent parent used in the present study are having the same background (i.e. Samba Mahsuri); hence backcrossing was restricted to two rounds. The recurrent parent genome (RPG) recovery was $78.5 \%$ (plant \# NLR-87) in the best $B C_{1} F_{1}$

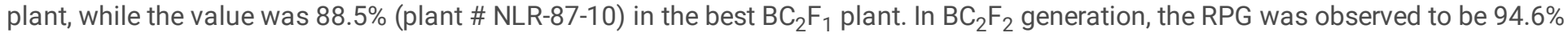
(line \# NLR-87-10-106) and 96\% (line \# NLR-87-10-106-44-54) in the selected best $B_{2} F_{4}$ lines. The estimation of linkage drag of donor segment in the best $\mathrm{BC}_{2} \mathrm{~F}_{4}$ lines (plant \# NLR-87-10-106-44-54) using graphical genotyping analysis (GGT) revealed that the extent of donor parent genome is restricted to $0.6 \mathrm{Mb}$ with respect to $\mathrm{Xa} 21$ on chromosome $11,1.3 \mathrm{Mb}$ with respect to $x a 13$ on chromosome 8 and $0.5 \mathrm{Mb}$ with respect to $x a 5$ on chromosome 5 , highlighting very high recovery of the genome of Nellore Mahsuri genome (up to $94.6 \%)$ at $\mathrm{BC}_{2} \mathrm{~F}_{4}$ (NLR-87-10-106). Similar results were observed in earlier studies where Xa21, xa13 and xa5 genes were introgressed into Samba Mahsuri, Jalmagna, wherein a recovery of $97 \%$ and $94.6 \%$ respectively was documented (Pradhan et al.2015; Sundaram et al. 2008, respectively). Few more studies also reported similar observations (Abhilash kumar et al. 2016, 2017; Balachiranjeevi et al. 2015, 2018; Basavraj et al. 2010; Fahim Ahmed et al. 2015, Hasan et al. 2015b; Rekha et al. 2018; Shanti et al. 2012; Swathi et al. 2019).

Phenotypic screening of the improved versions of the NLR 34449 against bacterial blight disease revealed that all the lines are resistant to the disease with a score of 1. Further, they were also resistant to blast with a score of 2-4 (Fig. 4, Table 2). The results are in agreement with earlier reports, wherein the bacterial blight resistance genes, Xa21, xa13 and xa5 were deployed either singly or in

Page 9/18 
combination (Dokku et al.2013a \& 2013b; Gitishree and Rao, 2015; Huang et al. 1997; Sanchez et al.2000; Singh et al. 2001; Sundaram et al. 2008; Yoshimura et al. 1995) and the derived lines showed resistance against the disease. The objective of the present study was to develop pyramided lines of NLR3449 with durable resistance against BB. In earlier studies, introgressed lines possessing two or more genes against bacterial blight were observed to possess higher level of resistance, possibly due to quantitative complementation (Sanchez et al. 2000; Sundaram et al. 2008). Cultivation of breeding lines of NLR34449 possessing the three resistance genes in bacterial blight endemic areas may be beneficial to farmers and also the resistance is expected to be more durable, as three resistance genes with distinct functions (Sundaram et al. 2009) have been deployed. There have been various reports, wherein a single major blast resistance gene likes Pi1 or Pi2 have shown the desired level of resistance against the disease (Fu et al. 2012). Similar to the recurrent parent, NLR 34449, which is highly resistant to blast disease, all the improved lines showed resistance against blast disease. Our preliminary analysis has indicated the possibility of presence of the major blast resistance gene, Pi1 in NLR34449, based on marker analysis (data not shown) and resistance in the breeding lines could be due to the presence of Pi1. The results observed in the present study with respect to resistance against BB and blast are in correspondence with the results obtained in earlier reports (Abhilash et al. 2016; Balachiranjeevi et al. 2015; Hari et al. 2013; Rekha et al.2018), wherein no negative interaction was observed between blast and BB resistance genes. The improved breeding lines with BB resistance using NLR 34449 as recurrent parent are expected to show high level of resistance against both the diseases. These two diseases are known to be widely prevalent and limiting the rice production in the Indian state of Andhra Pradesh (also known as Rice Bowl of South India) and also other Indian States (Aruna kumari et al. 2016).

Most of the improved lines were observed to be equivalent to NLR 34449 in terms of grain yield and other agromorphological characters and some of them were found to be superior to NLR 34449 with respect to yield (Table 3) and all the lines were showing good panicle exsertion with plant height equivalent to NLR 34449 and hence are non-lodging (Fig. 5). Further all the selected improved lines, possessing bacterial blight and blast resistance were observed to be retaining the medium slender grain type and fine-grain quality attributes of the NLR 34449 (Fig. 5). It can be expected that the bacterial blight and blast resistant lines of NLR 34449 developed through present study may useful for the farmers to get the same price in the market, similar to NLR 34449 as they are identical in terms of grain quality and yield, plus added advantage of resistance against two major diseases. One of the significant achievement of this study is the complete recovery of the yield and yield related traits along with grain quality features in the improved lines of NLR 34449 possessing bacterial blight and blast resistance. Combining phenotype-based selection with MAS in the present study was helpful in not only recovering good features of the recurrent parent, but also helpful in selection of superior lines (with better yield and panicle exsertion) as compared to the recurrent parent, NLR34449.

\section{Conclusion:}

The improved versions of Nellore mahsuri possessing BB and blast resistance, developed in the present study may offer a distinct advantage to farmers of NLR34449, whose fields are affected by both bacterial blight and blast. Further, Cultivation of such improved backcross derived lines of NLR34449 possessing resistance against bacterial blight and blast could help to improve rice production in the disease endemic areas in many states of India, wherein fine-grain type varieties like NLR34449, Samba Mahsuri, HMT Sona etc. are preferred. Further, the improved lines of NLR 34449 developed in this study can also be used as donors to transfer BB and blast resistance into other genetic backgrounds as they possess high yield and medium-slender grain type. Among the improved lines of NLR 34449, the backcross derived line \# NLR-87-10-106-44-54 possessing Xa21, xa13 and xa5 showed very good phenotype and better panicle exsertion along with high yield and diseases resistance and hence it has been identified as one of promising lines (Table 3). This line is being nominated for AICRIP trials and state trials for possible commercial release to farmers.

\section{Abbreviations}

NLR 34449: Nellore Mahsuri; ISM: Improved Samba Mahsuri; BB: Bacterial Blight; MABB: Marker-Assisted Backcross Breeding; ICARIIRR: Indian Counsil of Agriculture Research- Indian Institute of Rice Research; CSIR-CCMB: Council of Scientific \& Industrial ResearchCentre for Cellular \& Molecular Biology; ANGRAU: Acharya N.G. Ranga Agricultural University; MS: Medium Slender; RPG: Recurrent Parent Genome; GCV: Genotypic Coefficient of Variance; PCV: Phenotypic Coefficient of Variance ; DFF: Days to Fifty percent Flowering; PH: Plant Height; PL: Panicle Length; NGP: Number of Grains per Panicle; S. Em.: standard errors of mean; CV: Coefficient of Variance; GAM: Genetic advance in \% of mean 


\section{Declarations}

\section{Ethical approval and consent to participate:}

Not applicable

\section{Consent for Publication:}

Not applicable

\section{Availability of data and materials:}

The data and information generated from the study are available in our laboratory as hard and soft copies and can be shared based on request.

\section{Competing interests:}

The authors declare that they have no competing interests.

\section{Funding:}

Aleena is grateful to Bayer crop science for providing the financial assistance during my research

\section{Contribution of authors:}

AD carried out the present work and developed the improved versions of NLR 34449 with BB \& blast resistance and drafted the manuscript; PV, BSM, LGS, SLV, SRM provided the infrastructural facilities for developing the improved versions of NLR 34449, RMS conceptualized and supervised the experiments and critically reviewed the manuscript; RG constantly helped in developing the improved versions of NLR 34449; DT, PE, KM, SRK, SP, HG, KRR, DMA, HSK, LB, AM, PK, MBM LGS, PMS helped with crossings, field selections and data collection for three consecutive seasons. All authors read and approved the final manuscript.

\section{Acknowledgements:}

The first author would like to acknowledge the funding support provided by the M/s Bayer Crop Sciences for necessary support in doing research. The authors would also like to thank, Indian Council of Agricultural Research and Department of Biotechnology for meeting part of the funding requirements and thank Project Director, ICAR-IIRR and ANGRAU, Lam, Guntur for providing all the necessary facilities to carry out the research work.

\section{References}

1. Abhilash Kumar V, Balachiranjeevi CH, Bhaskar Naik S, Rambabu R, Rekha G, Madhavi KR (2016) Marker-assisted introgression of bacterial blight and blast resistance genes into RPHR 1005, restorer line of the popular rice hybrid, DRRH-3. J Plant Biochem Biot. doi:10.1007/s13562-016-0352z

2. Abhilash Kumar V, Balachiranjeevi CH, Naik B, Rekha G, Rambabu R, Harika G, Pranathi K, Hajira Sk, Anila M, Kousik M, Kale KR, Dilip Kumar R, Prasad MS, Hariprasad AS, Padmakumar AP, Laha GS, Balachandran SM, Madhav MS, Senguttuvel P, Kemparajau KB, Fiyaz R, Bentur RA, Virakatmath JS, Ravindra Babu BC V and Sundaram RM (2017) Marker-assisted pyramiding of bacterial blight and gall midge resistance genes into RPHR-1005, the restorer line of the popular rice hybrid DRRH-3. Mol Breed 37:86. doi:10.1007/s11032-017-0687-8 
3. Abhilash Kumar V, Balachiranjeevi CH, Bhaskar Naik S, Rambabu R, Rekha G, Pranathi K, Hajira SK, Anila M, Mahadevaswamy HK, Harika G, Hariprasad AS, Madhav MS, Laha GS, Prasad MS, Sundaram RM (2015) Marker-assisted introgression of genes conferring resistance against bacterial blight \& blast into RPHR-1005, the elite restorer line of the popular rice hybrid, DRRH-3. Int J Curr Res 7(11):22222-22228

4. Abhilash KV, Balachiranjeevi CH, Bhaskar NS, Rambabu R, Rekha G, Madhav KR, Vijay S, Pranathi K, Harika G, Mahadevaswamy HK, Anila M, Hajira SK, Yugander A, Hariprasad AS, Madhav M, Laha GS, Balachandran SM, Sundaram RM, Prasad MS (2016) Marker-assisted introgression of bacterial blight and blast resistance genes into RPHR 1005, restorer line of the popular rice hybrid, DRRH-3. J Plant Biochem Biotechnol 25(4):400-409

5. Anila M, Mahadevaswamy HK, Bhadana VP, Brajendra, Hajira SK, Pranath K, Chiranjeevi B, Bhaskar B, Abhilash V, Rekha G, Dhanalaxmi D, Vinod kumar B, Harika G, Kousik BVN, Dilip T, Balachandran SM, Neeraja CN, Mangrathia SK, Madhav MS, Sundaram RM (2014) Marker-assisted introgression of Pup1, a major QTL associated with tolerance to low soil phosphorus into the elite rice variety MTU1010. Progressive Research 9:735-738

6. Aruna Kumari K, Durgarani CV, Satturu V, Sarikonda KR, Chittoor PDR, Vutukri B, Laha GS, Nelli APK, Gattu S, Jamal M, Prasadbabu A, Hajira SK, Sundaram RM (2016) Marker Asiisted Pyramiding of genes conferring resistance against bacterial blight and blast diseases into Indian rice variety MTU1010. Rice Sci 23(6):306-316

7. Ashkani S, Rafii MY, Shabanimofrad M, Ghasemzadeh A, Ravanfar S, Latif MA (2014) Molecular progress on the mapping and cloning of functional genes for blast disease in rice (Oryza sativa L.). Curr Sci 36(2):353-367

8. Bai JY, Zhang Q, Jia XP, Chuan Y, Bao X (2006) Comparison of diferent foreground and background selection methods in markerassisted introgression. Acta Genet Sinica 33:1073-1080. doi:10.1016/ S0379-4172(06)60144-3

9. Balachiranjeevi CH, Bhaskar Naik S, Abhilash Kumar V, Harika G, MahadevSwamy HK, Hajira Sk, Dilip Kumar T, Anila M, Kale RR, Pranathi K, Koushik MBVN, Suneetha K, Bhadana VP, Yugender A, Hariprasad AS, Laha GS, Rekha G, Balachandran SM, Madhav MS, Senguttuvel P, Fiyaz AR, Viraktamath BC, Giri A, Swamy BPM (2018) Marker-assisted pyramiding of two major, broadspectrum bacterial blight resistance genes, Xa21 and Xa33 into an elite maintainer line of rice, DRR17B. PLOS ONE. https://doi.org/10.1371/journal.pone.0201271. Jauhar Ali, Sundaram, RM

10. Balachiranjeevi CH, Bhaskar NS, Abhilash V, Akanksha S, Viraktamath BC, Madhav MS, Hariprasad AS, Laha GS, Prasad MS, Balachandran SM, Neeraja CN, Satendra Kumar M, Senguttuvel P, Kemparaju KB, Bhadana VP, Ram T, Harika G, Mahadeva Swamy HK, Hajira SK, Yugander A, Pranathi K, Anila M, Rekha G, Kousik MBVN, Dilip Kumar T, Kulkarni SR, Giri A, Sundaram RM (2015) Marker-assisted introgression of bacterial blight and blast resistance into DRR17B, an elite, fine-grain type maintainer line of rice. Mol Breed 35:151

11. Basawaraj SH, Singh VK, Singh A, Singh A, Yadav S, Ellur RK, Singh D, Gopala Krishnan S, Nagarajan M, Mohapatra T, Prabhu KV, Singh AK (2010) Marker-assisted improvement of bacterial blight resistance in parental lines of Pusa RH10, a superfine grain aromatic rice hybrid. Mol Breed 2:293-305

12. Bhaskar Naik S, Balachiranjeevi CH, Abhilash V, Harika G, Laha GS, Prasad MS, Sundaram RM (2015) Introgression of Bacterial blight and blast resistance into the elite rice variety, Akshayadhan through marker-assisted backcross breeding. Int J Curr Res 7(8):18943-18946

13. Chen SC, Xu G, Lin XH, Zhang Q (2001) Improving bacterial blight resistance of 6078 , an elite restorer line of hybrid rice, by molecular marker-aided selection. Plant Breed 120:133-137

14. Devadath S (1989) Chemical control of bacterial blight of rice. In: IRRI (ed) Bacterial blight of rice. IRRI, Manila, pp 89-98

15. Dokku P, Das KM, Rao GJN (2013b) Genetic enhancement of host plant-resistance of the Lalat cultivar of rice against bacterial blight employing marker-assisted selection. Biotechnol Lett 35:1339-1348. doi:10.1007/s10529-013-1212-8

16. Dokku P, Das KM, Rao GJN (2013a) Pyramiding of four resistance genes of bacterial blight in Tapaswini, an elite rice cultivar, through marker assisted selection. Euphytica 192:87-96

17. Fahim Ahmed, Mohd Y, Rafii MR, Ismail, Abdul Shukor Juraimi, Harun Abdul Rahim, Fatah Abro Tanweer \& Mohammad Abdul Latif (2015) Recurrent parent genome recovery in different populations with theintrogression of Sub1 gene from a cross between MR219 and Swarna-Sub1. Euphytica. doi:10.1007/s10681-015-1554-5

18. Fu C, Wu T, Liu W, Wang F, Li J, Zhu X (2012) Genetic improvement of resistance to blast and bacterial blight of the elite maintainer line Rongfeng B in hybrid rice (Oryza sativa L.) by using marker-assisted selection. Afr J Biotechnol 11:13104-13114 
19. Gitishree D, Rao GJN (2015) Molecular marker assisted gene stacking for biotic and abiotic stress resistance genes in an elite rice cultivar. Front Plant Sci 6:698

20. Hajira SK, Sundaram RM, Laha GS, Yugander A, Balachandran SM, Viraktamath K, Sujatha BC, Balachiranjeevi CH, Pranathi K, Anila M, Bhaskar S, Abhilash V, Mahadevaswamy HK, Kousik M, Dilip Kumar T, Harika G, Rekha G (2016) A Single-Tube, Functional Marker-Based Multiplex PCR Assay for Simultaneous Detection of Major Bacterial Blight Resistance Genes Xa21, xa13 and $x a 5$ in Rice. Rice Sci 23(3):144-151

21. Hari Y, Srinivasarao K, Basavraj C, Viraktamath A, Hari Prasad S, Laha GS, Ahmed I, Md, Natraj Kumar P, Sujatha K, Srinivasa Prasad M, Manish Pandey, Ramesha MS, Neeraja CN, Balachandran SM, Rani NS, Balachandra K, Madan Mohan K, Venkata S, ArunSama K, HajiraShaik, Balachiranjeevi CH, Pranathi K, Ashok Reddy, Seshumadhav M, Sundaram RM (2013) Marker assisted introgression of bacterial blight and blast resistance into IR58025B, an elite maintainer line of rice. Plant Breed 132(6):586-594

22. Hasan MM, Rafii MY, Ismail MR, Mahmood M, Alam MA, Rahim HA, Malek MA, Latif MA (2015b) Introgression of blast resistance genes into the elite rice variety MR263 through marker-assisted backcrossing. J Sci Food Agric. doi:10.1002/jsfa.7222

23. Hasan MM, Rafii MY, Ismail MR, Mahmood M, Rahim HA, Alam MA, Malek MA, Ashkani S, Malek MA, Latif MA (2015a) Marker assisted backcrossing: a useful method for rice improvement. Biotechnol Biotechnol Equip 29:2(237-254.

http://dx.doi.org/10.1080/13102818.2014.995920

24. Hospital F, Charcosset M (1997) Marker-assisted introgression of quantitative trait loci. Genetics 147:1469-1485

25. http://www.kvknellore-angrau.org/index.php

26. https://doi.org/10.1371/journal.pone.0201271

27. Huang N, Angeles ER, Domingo J, Magpantay G, Singh S, Zhang G, Kumaravadivel N, Bennett J, Khush GS (1997) Pyramiding of bacterial blight resistance genes in rice: marker assisted selection using RFLP and PCR. Theor Appl Genet 95:313-320

28. IRRI (1996) Standard Evaluation System for Rice 4th ed International Rice Research Institute Manila Philippines

29. IRRI (2013) Standardization evaluation system for rice. International Rice Research Institute, P.0. Box 933, 1099 Manila. Philippines 5:18

30. Ishiyama S (1922) Studies of bacterial leaf blight of rice. Rep Imp Agric Stn Konosu 45233-261

31. Jena KK, Mackill DJ (2008) Molecular markers and their use in marker-assistedselection. in rice Crop Sci 48:1266-1276

32. Joseph M, Gopalakrishnan S, Sharma RK, Singhm VP, Singhm AK, Singhm NK, Mohapatra T (2004) Combining bacterial blight resistance and Basmati quality characteristics by phenotypic and molecular marker-assisted selection in rice. Mol Breed 13:377387

33. Ratna Madhavi K, Rambabu R, Abhilash Kumar V, Vijay Kumar S, Aruna J, Ramesh S, Sundaram RM, Laha GS, Sheshu Madhav M, Ravindra babu V, Srinivas Prasad M (2016) Marker assisted introgression of blast (Pi-2 and Pi-54) genes in to the genetic background of elite, bacterial blight resistant indica rice variety. Improved Samba Mahsuri Euphytica 212:331-342

34. Kauffman HE, Reddy APK, Hsieh SPY, Merca SD (1973) An improved technique for evaluating resistance of rice varieties to Xanthomonas oryzae. Plant Diseases Report 56:537-540

35. Khush GS (2005) what it will take to feed 5.0 billion rice consumers in 2030. Plant Mol Bio 59:1-6. doi:10.1007/s11103-0052159-5

36. Kim SM, Suh JP, Qin Y, Noh TH, Reinke RF, Jena KK (2018) Identification and fine mapping of a new resistance gene, Xa40, conferring resistance to bacterial blight races in rice (Oryza sativa L.). Theor Appl Genet 128:1933-1943. https://doi.org/10.1007/s00122-015-2557-2 PMID:26081948

37. Kim SM, Jung PS, Yang Q, Tae HN, Russell F, Reinke KK, Jena (2015) Identification and fine-mapping of a new resistance gene, Xa40, conferring resistance to bacterial blight races in rice (Oryza sativa L.). Theor Appl Genet 128:1933-1943

38. Lalitha DG, Pranitha K, Vinay S, Lalitha SM (2013) Improvement of resistance to bacterial blight through marker assisted backcross breeding and field validation in rice (Oryza sativa L.). Res J Biol Sci 1:52-66

39. Madhavi K, Sundaram RM, Laha GS, Rambabu, Ratnala, Kumar S, Aruna J, Kumar V, Sheshu madhav, Maganti C, Viraktamath Prasad M (2013) Combining blast and bacterial blight resistance in to rice cultivar improved samba mahsuri through marker assisted selection. 10.13140/RG.2.1.1349.5285

40. Mahadevaswamy HK (2018) Marker-assisted introgression of Pup1 into the elite rice variety, Improved Samba Mahsuri. Ph. D (Ag.) Thesis, Professor Jayashankar Telangana State Agricultural University, Rajendranagar, Hyderabad, India

Page $13 / 18$ 
41. Magar MM, Rani D, Vanisree ChV, Jamaloddin S, Md, Swathi G, Sheshumadhav M, Anuradha G, Sri Chandana B, Siddiq EA (2012) Marker assisted selection for identification of recombinants for bacterial blight and blast resistance in segregating populations of Cottondora Sannalu. Oryza 51(2):105-115

42. Miah G, Rafii MY, Ismail MR, Puteh AB, Rahim HA, Latif MA (2015) Recurrent parent genome recovery analysis in a markerassisted backcrossing program of rice (Oryza sativa L.). C R biologies 338:83-94. doi 10.1016/J.CRVI.2014.11.003

43. Neelam K, Mahajan R, Gupta V, Bhatia D, Gill BK, Komal R, Lore JS, Mangat GS, Singh K (2019) High-resolution genetic mapping of a novel bacterial blight resistance gene xa-45(t) identified from Oryza glaberrima and transferred to Oryza sativa. Theor Appl Genet 133(3):689-705. doi 10.1007/s00122-019-03501-2

44. Nguyen Nguu Van and Ferrero Aldo (2006) Meeting the challenges of global rice production. Paddy Water Environ 4:1-9. doi:10.1007/s10333-005-0031-5

45. Ou SH (1985) Rice Diseases. Common wealth Mycological Institute, Kew. Pp: 380

46. Pradhan SK, Nayak DK, Mohanty S, Behera L, Barik SR, Pandit E, Lenka S, Anandan A (2015) Pyramiding of three bacterial blight resistance genes for broad-spectrumresistance in deepwater rice variety. Jalmagna Rice 8:19

47. Ramalingam J, Savitha P, Ganesh A, Saraswathi R, Chandrababu R (2017) Functional Marker Assisted Improvement of Stable Cytoplasmic Male Sterile Lines of Rice for Bacterial Blight Resistance. Front Plant Sci 8:article 1131

48. 10.1007/s13562-018-0455-9

Rekha G, Abhilash Kumar V, Viraktamath BC, Pranathi K, Kousik MBVN, Laxmi Prasanna B, Backiyalakshmi C, Pragya Sinha, Ravindra R, Kale, Hajira SK, Bhaskar S, Balachiranjeevi CH, Swapnil Kulkarni, Harika G, Punniakotti E, Dilip kumar T, Yugander A, Mahadev HK, Anila M, Chaitra K, Praveen M, Laha GS, Prasad MS, Balachandran SM, Senguttuvel P, Fiyaz A, Jyothi badri, Ravindra Babu V and Sundaram RM (2018) Marker-assisted improvement of blast resistance of the popular, high yielding, finegrain type, bacterial blight resistant rice variety, Improved Samba Mahsuri. J Plant Biochem Biot. doi.org/10.1007/s13562-0180455-9

49. Ronald PC, Albano B, Tabien R, Wu Abenes L, Mc Couchand S, Tanksley S (1992) Genetic and physical analysis of the rice bacterial blight resistance locus, Xa21. Mol Gen Genet 235:113-120

50. Sanchez AC, Brar DS, Huang N, Li Z, Khush GS (2000) Sequence Tagged Site marker-assisted selection for three bacterial blight resistance genes in rice. Crop Sci 40:792-797

51. Shivalingaiah, Umesha S (2011) Characterisation of Xanthomonas oryzae pv. oryzae from major rice growing regions of Karnataka. Bioscan 6(1):5-10

52. Singh S, Sidhu JS, Huang N, Vikal Y, Li Z, Brar DS, Dhaliwal HS, Khush GS (2001) Pyramiding three bacterial blight resistance genes (xa5, xa13 and Xa21) using marker-assisted selection into indica rice cultivar PR106. Theor Appl Genet 102:1011-1015

53. Srinivas Prasad M, Sheshu Madhav M, Laha GS, Ladha Lakshmi D, Krishnaveni D, Mangrauthia SK, Balachandran SM, Sundaram RM, Aruna Kanthi B, Madhan Mohan K, Ratna Madhavi K, Kumar V, Viraktamath BC (2009) Rice blast disease and its management. Technical Bulletin No57/2011, Directorate of Rice Research (ICAR), Rajendranagar, Hyderabad-500 030, Andhra Pradesh, India: 52

54. Srinivasan B, Gnanamanickam S (2005) Identification of a new source of resistance in wild rice, Oryza rufipogon to bacterial blight of rice caused by Indian strains of Xanthomonas oryzae pv. oryzae. Current Sci 88:25

55. Suk Man Kim (2018) Identifcation of novel recessive gene xa44(t) conferring resistance to bacterial blight races in rice by QTL linkage analysis using an SNP chip. Theor Appl Genet. doi.org/10.1007/s00122-018-3187-2

56. 10.1186/s12284-014-0012-7

Sundaram RM, Chatterjee S, Oliva R, Laha GS, Leach JE, Sonti RV (2014) Update on bacterial blight of rice: fourth international conference on bacterial blight rice 7:12. doi:10.1186/s12284-014-0012-7

57. Sundaram RM, Priya MRV, Laha GS, Shobha Rani N, Srinivasa Rao P, Balachandran SM, Ashok Reddy G, Sarma NP, Sonti RV (2009) Introduction of bacterial blight resistance into Triguna, a high yielding, mid-early duration rice variety by molecular marker assisted breeding. Biotechnol J 4:400-407

58. Sundaram RM, Vishnupriya MR, Biradar SK, Laha GS, Reddy AG, Rani NS, Sarma NP, Sonti RV (2008) Marker assisted introgression of bacterial blight resistance in Samba Mahsuri, an elite indica rice variety. Euphytica 160:411-422

59. Sundaram RM, Laha GS, Viraktamath BC, Sujatha K, Natarajkumar P, Hari Y, Srinivasa Rao K, Reddy CS, Balachandran SM, Madhav MS, Hajira SK, Rani NS, Vishnupriya MR, Sonti RV (2011) Marker Assisted Breeding for development of Bacterial Blight

Page $14 / 18$ 
Resistant Rice. In: K. Muralidharan and E.A. Siddiq (eds.) Genomics and Crop Improvement: Relevance and Reservations, Institute of Biotechnology, Acharya NG Ranga Agricultural University, Hyderabad. 154-182

60. Swathi G, Rani CVD, Jamaloddin M, Madhav MS, Vanisree S, Anuradha C, Kumar NR, Arun Prem Kumar N, Aruna Kumari K, Bhogadhi SC, Ramprasad E, Sravanthi P, Krishnam Raju S, Bhuvaneswari, Rajan CPD, Jagadeeswar R (2019) Marker assisted introgression of the major bacterial blight resistance genes, $\mathrm{Xa} 21$ and $\mathrm{xa} 13$, and blast resistance gene, Pi54, into the popular rice variety, JGL1798. Mol Breed 39:58. doi.org/10.1007/s11032-019-0950-2

61. Van Berloo R (1999) GGT: software for the display of graphical genotypes. J Hered 90:328-329

62. Yoshimura S, Yoshimura A, Iwata N, McCouch SR, Abenes ML, Baraoidian MR, Mew TW, Nelson RJ (1995) Tagging and combining bacterial blight resistance genes in rice using RAPD and RFLP markers. Mol Breed 1:375-387

\section{Figures}

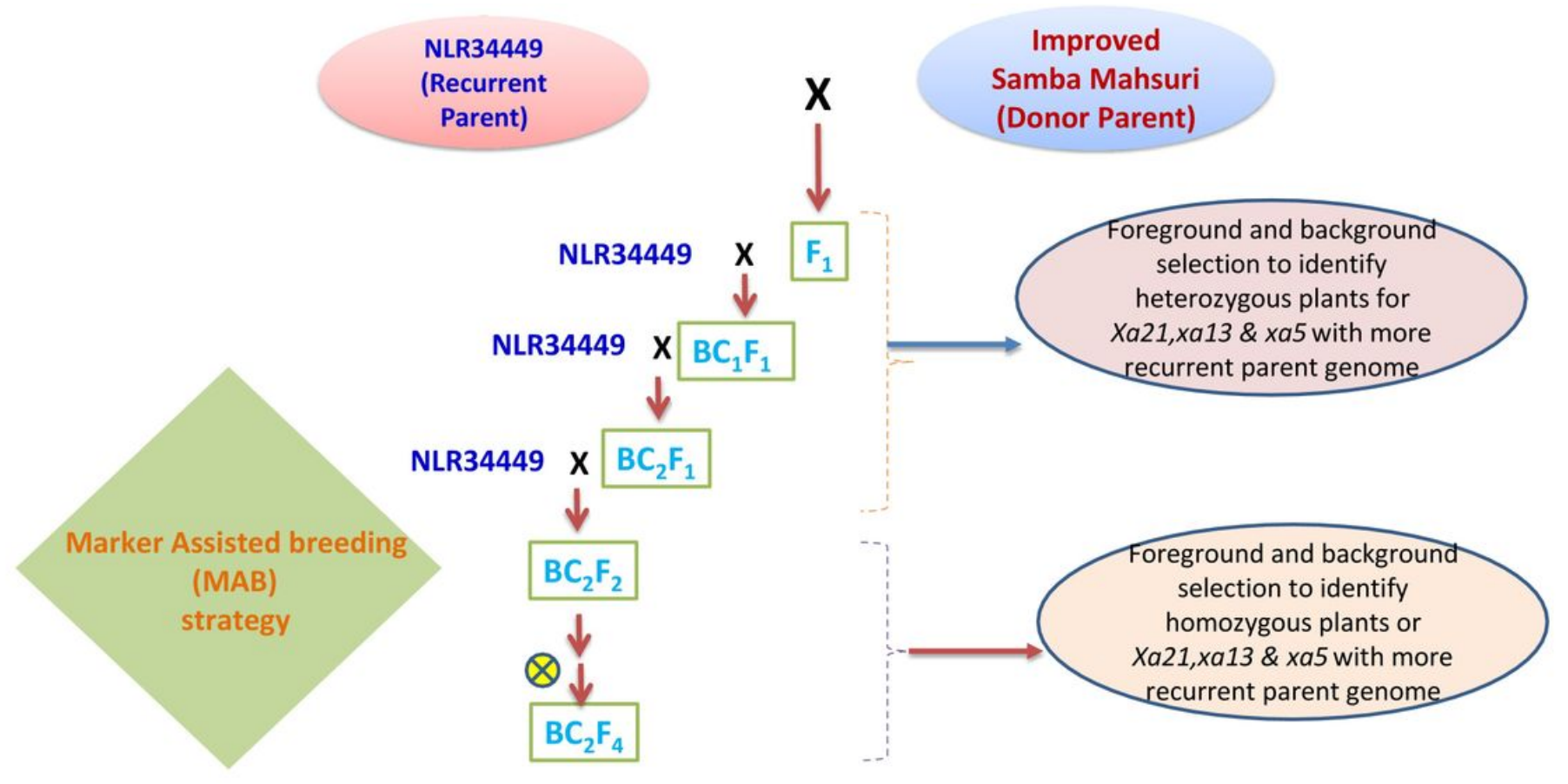

\section{Figure 1}

Outline of the crossing scheme. Nellore Mahsuri (NLR 34449) was crossed with Improved Samba Mahsuri (ISM) possessing bacterial blight resistant genes $\mathrm{Xa21}$, xa13, xa5 in order to build bacterial blight resistance through step-wise, marker assisted backcross breeding strategy 

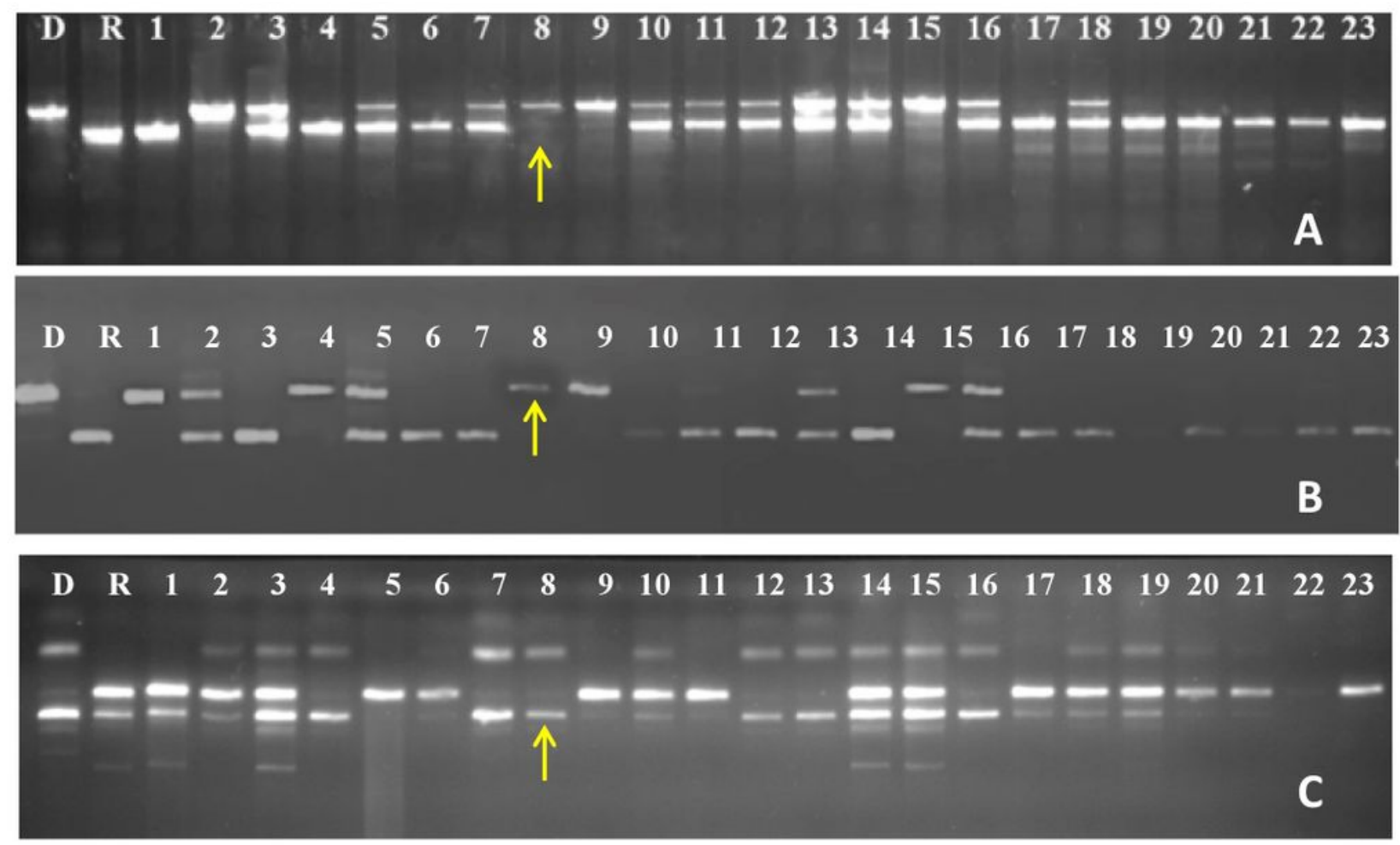

Figure 2

Identification of homozygous BC2F2 plants possessing Xa21+xa13+xa5. (A) Anlyis of Xa21 gene using pTA248 marker (B) Analysis of xa13 gene using xa13prom marker (C) Analysis of xa5 gene using xa5FM marker.; R-Recurrent parent NLR34449; D- Donor parent ISM; 1-25 -test samples. Arrows indicate a positive plant possessing all the three genes in homozgyous condition.
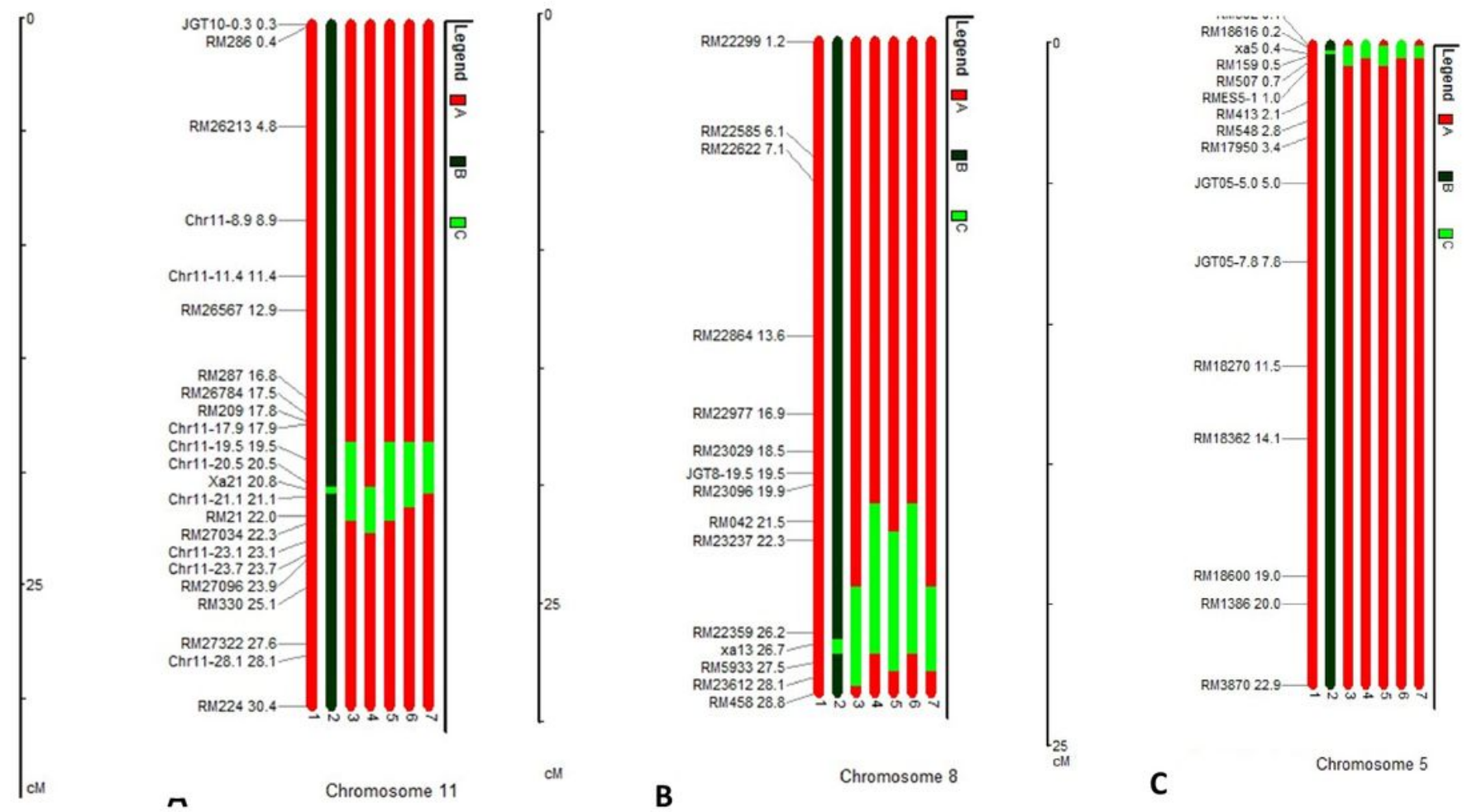

Page $16 / 18$ 


\section{Figure 3}

Analysis of donor genome introgression in the chromosomal region around the BB resistance genes, Xa21, xa13 and xa5 in the selected BC2F4 plants through graphical genotype analysis. A: Extent of background genome recovery in the genomic regions in the vicinity of Xa21 on Chromosome 11, and B: Extent of background genome recovery in the genomic regions in the vicinity of xa13 on Chromosome 8, and C: Extent of background genome recovery in the genomic region in the vicinity of xa5 on Chromosome 5

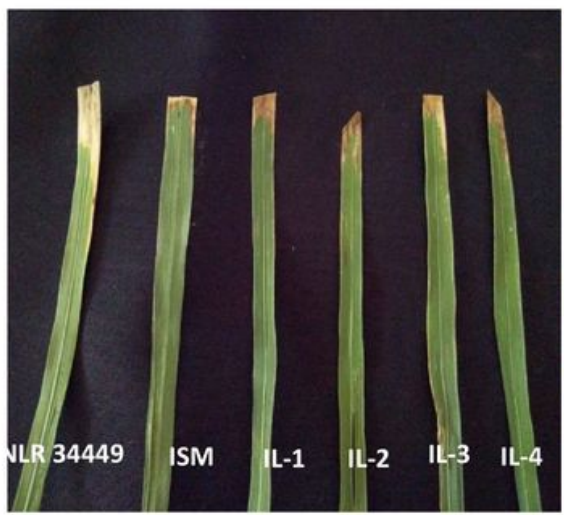

A

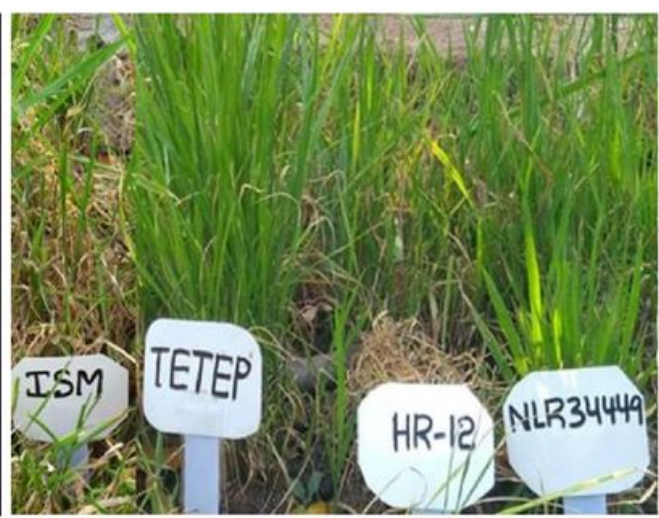

B

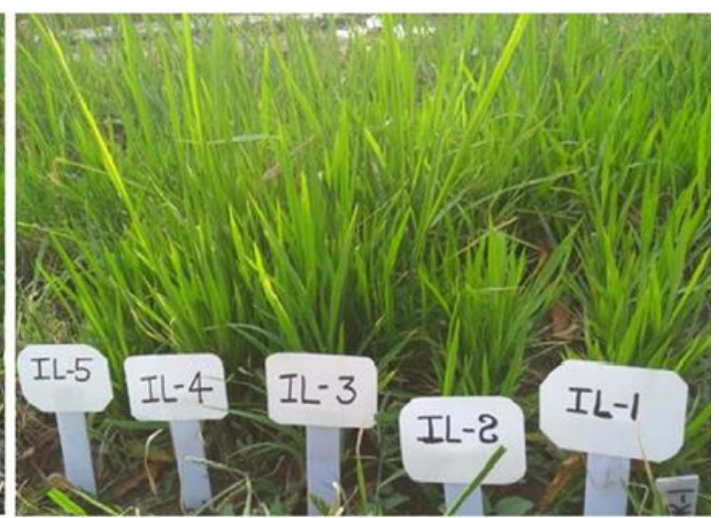

.

\section{Figure 4}

Phenotypic screening of NLR 34449 derived backcross lines for their resistance against bacterial blight and blast; A: Screening of the improved lines against bacterial blight disease. NLR 34449 (Susceptible check), ISM (Resistant check); IL-1 to IL-4- selected BC2F4 lines of NLR 34449. B: Screening against blast disease in Uniform Blast Nursery. Tetep, NLR 34449 (Resistant checks); ISM, HR 12 (Susceptible checks), IL-1 to IL-5: Improved lines of NLR 34449 at BC2F5 generation.

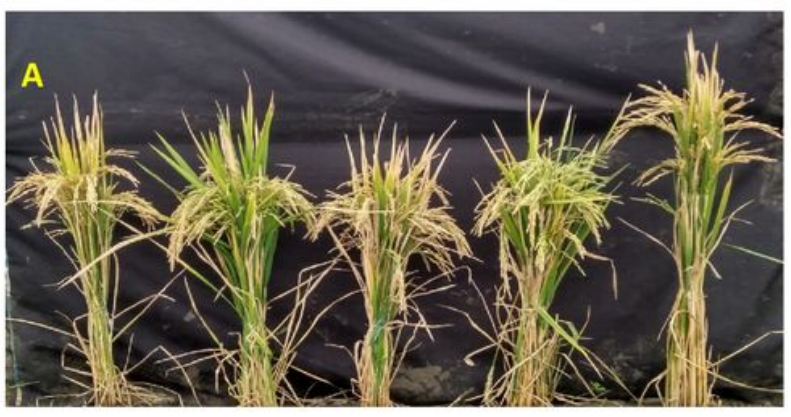

NLR34449
IL-1
ISM
IL-3

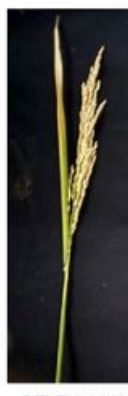

NLR34449 IL
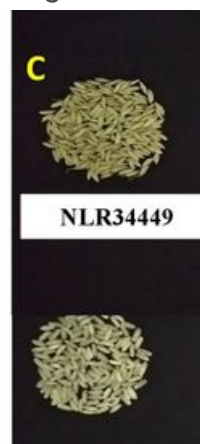

NLR34449

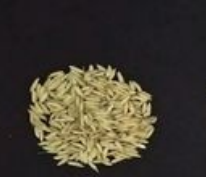

IL-1

IL-2

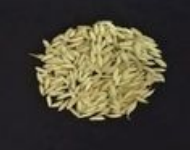

IL-3

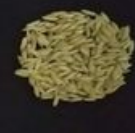

ISM

\section{Figure 5}

Improved BB and blast resistant lines of NLR 34449. (A)The best Bacterial blight (BB) and Blast Resistant Introgression Lines (ILs) of NLR 34449 with high yield (B) The best Bacterial blight (BB) and Blast resistant panicles with high grain number (C) Improved Bacterial blight (BB) and blast lines grain number and grain quality 


\section{Supplementary Files}

This is a list of supplementary files associated with this preprint. Click to download.

- Supplemetarytables.docx 